\title{
Metabolism and habitat competition in the polychaete Nereis virens
}

\author{
Hélène Lemieux ${ }^{1}$, Pierre U. Blier ${ }^{1, *}$, France Dufresne $^{1}$, Gaston Desrosiers ${ }^{2}$ \\ 'Département de Biologie, ${ }^{2}$ Département d'Océanographie, Université du Québec à Rimouski, 300 allée des Ursulines, \\ Rimouski, Québec, Canada G5L 3A1
}

\begin{abstract}
The relationship between metabolism and performance during habitat competition in the polychaete Nereis virens (Sars) was determined. Twenty paired habitat competition experiments were initiated between individuals of similar body mass. The outcome of the competition and the time spent competing for the burrow were noted for each encounter. Protein and lipid contents as well as enzyme activity (cytochrome $\mathrm{C}$ oxidase, lactate dehydrogenase, and pyruvate kinase) were compared between winners and losers. There were no significant differences between winners and losers for all parameters. There was, however, a significant relationship between fight duration and enzyme activity for winners. Individuals that won a fight rapidly had more cytochrome $C$ oxidase activity than individuals who fought longer to gain access to the burrow. We conclude that metabolic capacities are not correlated with the outcome of habitat competition but that aerobic capacity is an important predictor of fight duration.
\end{abstract}

KEY WORDS: Polychaete Metabolism - Habitat competition - Cytochrome C oxidase - Lactate dehydrogenase Pyruvate kinase

\section{INTRODUCTION}

One major focus of physiological ecology is to examine the adaptive value of physiological performance. In order to evolve by natural selection, physiological traits must be variable, heritable, and directly associated with fitness. Significant individual variation in physiological performance has been reported for many physiological traits including oxygen consumption, enzymatic activities, and locomotor capacities (Pough 1989). In addition, several types of physiological performance (speed, defensive behaviors, growth rates, thermoregulation) show some degree of heritability (Bennett 1987). Energetic metabolism is tightly correlated to activity capacity in animals (Holloszy \& Coyle 1984, Guderley \& Blier 1988) and could be a functional link between the genotype and physiological performance. Very few studies have examined whether variation in physiological traits is directly correlated with fitness. The most commonly studied physiological

\footnotetext{
- Addressee for correspondence

E-mail: pierre_blier@uqar.uquebec.ca
}

parameters have been burst speed, maximal exertion, and endurance (reviewed by Bennett 1991). While minor differences in speed or exertion may mean success or failure in predator-prey interactions, these differences in physiological activities remain only indirectiy correlated with fitness.

In this study we examine the relationship between metabolic capacities and territorial defense in the polychaete Nereis virens (Sars). This worm is a common species of the estuary and the Gulf of St. Lawrence, Canada (Desrosiers \& Brêthes 1984, Desrosiers et al. 1984). Immature individuals of $N$. virens occur at high densities in the upper intertidal zone (Miron \& Desrosiers 1990, Desrosiers et al. 1994). These individuals migrate downshore in the fall of their third year (Caron et al. 1993, Desrosiers et al. 1994) and compete for burrows with mature individuals already established. Encounters between immature and mature individuals are highly aggressive and often terminated by the expulsion of the intruder (Miron et al. 1992a). Thus Nereis populations may be regulated by competition for habitat. Territorial behavior in $N$. virens has been shown to be a predator refuge function and 
directly related to fitness (Miron 1991). Maximal metabolic capacity may be a determinant of success in competing for habitats and thereby affect fitness.

This study compares the metabolic profiles of individuals after confrontation for the occupation of a burrow in order to determine if these are correlated with the outcome of competition. The 3 enzymes used as metabolic markers were cytochrome $\mathrm{C}$ oxidase (CCO), pyruvate kinase (PK), and lactate dehydrogenase (LDH). CCO was chosen as a marker of aerobic metabolism since a previous study on pelagic worms has shown that oxygen consumption rates are correlated with mitochondrial markers (Thuesen \& Childress 1993). PK is a regulatory enzyme of glycolysis and its activity is correlated with the intensity of glucose or glycogen catabolism that can be supported by a tissue or an organism. As the glucose or glycogen metabolism usually provides a greater yield of ATP per unit time than lipid metabolism, we postulated that the energy demand generated by bursts of activity during confrontations would be supported primarily by glycolysis. The pyruvate produced by glycolysis can be transformed to lactate by lactate dehydrogenase (anaerobic glycolysis) or it can be fully oxidized in the mitochondria. Anaerobic glycolysis is usually the metabolic pathway that is mobilized when a high level of energy production is required for a short burst of activity (for a complete survey of animal exercise biochemistry, see Newsholme \& Leech 1983, Hochachka \& Somero 1984). As LDH is the only strictly anaerobic enzyme of glycolysis, its activity combined with PK is a good marker of the anaerobic capacity of an organism. As fights require short and powerful peaks of activity which may be modulated by energetic metabolism, we predicted that winners would have higher metabolic capacity (as expressed by enzyme activities) than losers.

\section{MATERIALS AND METHODS}

Competition experiments. Nereis virens were collected from homogeneous sandy sediments in the intertidal flat of l'Anse à l'Orignal, $25 \mathrm{~km}$ from Rimouski, Québec, Canada. They were maintained in the laboratory at $10^{\circ} \mathrm{C}$ and 20 ppm salinity in sandy sediments for a minimum of $5 \mathrm{~d}$. No supplementary food was provided prior to the experiments. The experimental set-up consisted of a U-shaped plastic burrow (6 mm diameter and $15 \mathrm{~cm}$ depth) placed into a $15 \mathrm{~cm}$ plastic container with foam and seawater. The foamy sediment was used to prevent worms from digging other burrows and hence forced the establishment of a single worm in the plastic burrow. The plastic container was covered with dark plastic to prevent light penetration as the prospecting behavior of this species is inhibited by light (Miron 1991). The worms were introduced in a container connected to the burrow but exposed to light to further force the settlement into the burrow

Prior to confrontations each worm was individually acclimated in an artificial burrow for $24 \mathrm{~h}$. The experiment was initiated by placing 2 worms of similar mass head to head at each extremity of a new unoccupied burrow. As after every confrontation only 1 individual gained access and occupation of the burrow, this one was classified as the winner and the one that was rejected outside was classified as the loser. The duration before settlement in the burrow was recorded for each confrontation. After confrontation, worms were frozen and kept at $-80^{\circ} \mathrm{C}$ for a maximum of 2 mo.

Enzymatic assays. Whole animals were homogenized in 4 volumes of ice cold imidazole-HCl buffer (100 mM, pH 7.4) using three 10 s bursts with a Tekmar homogenizer. Enzyme activities were measured at $25^{\circ} \mathrm{C}$ using a Perkin Elmer UV-Visible spectrophotometer (lambda 11). All assays were run in duplicate and specific activities were expressed as $\mu \mathrm{mol} \mathrm{min}^{-1}$ $\mathrm{mg}^{-1}$ protein. Condition for enzyme assays were as follows:

(1) Cytochrome Coxidase (CCO): $100 \mathrm{mM}$ potassium phosphate and $0.05 \mathrm{mM}$ cytochrome $\mathrm{C}_{\text {; }} \mathrm{pH}$ 7.4. Cytochrome $\mathrm{C}$ was reduced by the addition of dithionite and the solution was bubbled with air to eliminate the excess reducing agent (Hodges \& Leonard 1974). Reactions were run against a control consisting of $50 \mathrm{mM}$ cytochrome $\mathrm{C}$ oxidized with the addition of potassium ferricyanide $(0.03 \%)$. Activity was measured by following the oxidation of cytochrome $\mathrm{C}$ at $550 \mathrm{~nm}$.

(2) Lactate dehydrogenase (LDH): $100 \mathrm{mM}$ imidazole$\mathrm{HCl}_{1} 0.16 \mathrm{mM}$ NADH and $6.0 \mathrm{mM}$ pyruvate; $\mathrm{pH} 7.4$

(3) Pyruvate kinase (PK): $100 \mathrm{mM}$ imidazole- $\mathrm{HCl}$, $10 \mathrm{mM} \mathrm{MgCl}_{2}, 50 \mathrm{mM} \mathrm{KCl}, 5 \mathrm{mM} \mathrm{ADP}, 0.2 \mathrm{mM} \mathrm{NADH}$, LDH in excess and $5.0 \mathrm{mM}$ phosphoenolpyruvate; $\mathrm{pH}$ 7.4. Activities of LDH and PK were measured following the oxidation of $\mathrm{NADH}$ at $340 \mathrm{~nm}$.

We used millimolar extinction coefficients of 29.5 for reduced cytochrome $\mathrm{C}$ and 6.22 for $\mathrm{NADH}$.

Protein and lipid analyses. Total protein and lipid contents were determined using the Bradford (1976) and Frings et al. (1972) methods respectively.

Statistical analyses. SYSTAT software was used for all statistical analyses. Student's paired $t$-tests were used to compare average mass, protein content, lipid content, and enzyme activities between overall winners and losers. We also compared physiological parameters among winners of encounters that lasted from: (1) 0 to $1 \mathrm{~min}$, (2) 1 to $2 \mathrm{~min}$, and (3) $2 \mathrm{~min}$ and more Kruskal-Wallis tests were used for these analyses since 
Table 1. Nereis virens. Comparisons of different physiological parameters for overall winners and losers. CCO: cytochrome C oxidase; LDH: lactate dehydrogenase; PK: pyruvate kinase. p-values from a paired Student's $t$-test

\begin{tabular}{|lcccccc|}
\hline & $\begin{array}{c}\text { Body mass } \\
(\mathrm{g})\end{array}$ & $\begin{array}{c}\text { Protein content } \\
\left(\mathrm{mg} \mathrm{g}^{-1}\right)\end{array}$ & $\begin{array}{c}\text { Lipid content } \\
\left(\mathrm{mg} \mathrm{g}^{-1}\right)\end{array}$ & $\begin{array}{c}\text { CCO activity } \\
\left(\mathrm{U} \mathrm{g}^{-1} \text { protein) }\right.\end{array}$ & $\begin{array}{c}\text { LDH activity } \\
\left(\mathrm{Ug}^{-1} \text { protein) }\right.\end{array}$ & $\begin{array}{c}\text { PK activity } \\
\text { (U g }\end{array}$ \\
\hline Winners $(\mathrm{n}=20)$ & $1.3 \pm 0.9$ & $36.4 \pm 10.0$ & $10.8 \pm 5.1$ & $51 \pm 23$ & $750 \pm 300$ & $1180 \pm 460$ \\
Losers $(\mathrm{n}=20)$ & $1.3 \pm 1.0$ & $38.7 \pm 10.1$ & $12.3 \pm 5.8$ & $58 \pm 34$ & $800 \pm 340$ & $1220 \pm 430$ \\
& $\mathrm{p}=1.0$ & $\mathrm{p}=0.386$ & $\mathrm{p}=0.224$ & $\mathrm{p}=0.258$ & $\mathrm{p}=0.585$ & $\mathrm{p}=0.720$ \\
\end{tabular}

some categories included a small number of individuals and normality assumptions were violated. MannWhitney $U$-tests were employed a posteriori (for the same reasons as above). The same tests were used to compare losers. Relationships between enzyme activity and worm size were examined using regression analyses. Significance was assessed at the 0.05 level for all tests.

\section{RESULTS}

\section{Competitive interactions}

All 20 pairwise competition tests resulted in the settlement of only 1 individual (winner) in the burrow. The duration of settlement varied from less than 1 min to $2 \mathrm{~h}$, with $75 \%$ of encounters resolved in less than $2 \mathrm{~min}$. Aggressive interactions were frequent and 2 of the fights resulted in the death of 1 of the competitors. $\mathrm{p}=0.949 ; \mathrm{PK}: \mathrm{p}=0.905)$, and more than 2 min (CCO $\mathrm{p}=0.449 ;$ LDH: $\mathrm{p}=0.846 ;$ PK: $\mathrm{p}=0.915$ ).

Individual body mass was negatively correlated with $\mathrm{CCO}$ activity but this relationship was weak (Fig. 1A). Both LDH and PK activities showed no significant relationship with body mass (Fig. 1B, C).

\section{DISCUSSION}

In contrast to our prediction, there was no correlation between the outcome of a confrontation and anaerobic glycolytic capacity in Nereis virens (as expressed by $\mathrm{LDH}$ and PK activities). According to the relatively low level of glycolytic enzyme in this species and in other polychaetes (Thuesen \& Childress 1993), the metabolic poise of these species appears aerobic. For example the LDH/CCO ratio that we measured (14.2) is closer to the value found for aerobic (20) than for anaerobic muscle (500) in the rainbow trout Oncorhynchus mykiss (Thibault et al. 1997). These results emphasize the

\section{Physiological parameters}

There were no significant differences in enzyme activity between overall winners and losers (Table 1). In addition, body mass, protein contents, and lipid contents did not differ between the 2 groups (Table 1). Worms that won fights rapidly $k<1 \mathrm{~min}$ and 1 to $2 \mathrm{~min}$ ) had significantly more cytochrome $\mathrm{C}$ oxidase activity than worms that fought longer to gain access to the burrow (>2 min) (Table 2). Losers did not show significant differences in enzyme activity according to the duration of the battle ( $p>$ 0.05). Body mass, protein contents and lipid contents were not significantly different between slow and fast winners (Table 3). There were no significant differences in enzyme activity between winners and losers of fights lasting less than $1 \mathrm{~min}$ (CCO: $p=0.808$; LDH: $p=0.345 ;$ PK: $p=$ 0.331 ), 1 to 2 min (CCO: $p=0.504 ; \mathrm{LDH}$ :
Table 2. Nereis virens. Enzyme activity for winners from fights of different durations. Groups with different letters are significantly different at the 0.05 level. p-values from Kruskal-Wallis tests

\begin{tabular}{|lcccc|}
\hline $\begin{array}{l}\text { Duration } \\
\text { (min) }\end{array}$ & $\mathrm{n}$ & $\begin{array}{c}\text { CCO activity } \\
\left(\mathrm{Ug}^{-1} \text { protein }\right)\end{array}$ & $\begin{array}{c}\mathrm{LDH} \text { activity } \\
\left(\mathrm{Ug}^{-1} \text { protein }\right)\end{array}$ & $\begin{array}{c}\text { PK activity } \\
\left(\mathrm{Ug}^{-1} \text { protein }\right)\end{array}$ \\
\hline $0-1$ & 6 & $65.3 \pm 25.2^{\mathrm{A}}$ & $760.0 \pm 370.0$ & $1209.5 \pm 405.0$ \\
$1-2$ & 9 & $51.0 \pm 17.6^{\mathrm{A}}$ & $694.7 \pm 265.9$ & $1162.3 \pm 402.1$ \\
$>2$ & 5 & $\begin{array}{c}32.4 \pm 16.1^{\mathrm{B}} \\
\mathrm{p}=0.038\end{array}$ & $\begin{array}{c}854.0 \pm 303.9 \\
\mathrm{p}=0.535\end{array}$ & $\begin{array}{c}1195.4 \pm 681.4 \\
\mathrm{p}=0.877\end{array}$ \\
\hline
\end{tabular}

Table 3. Nereis virens. Protein and lipid contents for winners from fights of different durations. p-values from Kruskal-Wallis tests

\begin{tabular}{|lcccc|}
\hline $\begin{array}{l}\text { Duration } \\
\text { (min) }\end{array}$ & $\mathrm{n}$ & $\begin{array}{c}\text { Body mass } \\
(\mathrm{g})\end{array}$ & $\begin{array}{c}\text { Protein content } \\
\left(\mathrm{mg} \mathrm{g}^{-1}\right)\end{array}$ & $\begin{array}{c}\text { Lipid content } \\
\left(\mathrm{mg} \mathrm{g}^{-1}\right)\end{array}$ \\
\hline $0-1$ & 6 & $0.7 \pm 0.2$ & $29.7 \pm 8.4$ & $14.0 \pm 3.2$ \\
$1-2$ & 9 & $1.5 \pm 1.0$ & $38.1 \pm 9.2$ & $10.3 \pm 6.0$ \\
$>2$ & 5 & $1.7 \pm 1.1$ & $41.4 \pm 11.6$ & $7.6 \pm 3.9$ \\
& & $\mathrm{p}=0.116$ & $\mathrm{p}=0.078$ & $\mathrm{p}=0.086$ \\
\hline
\end{tabular}



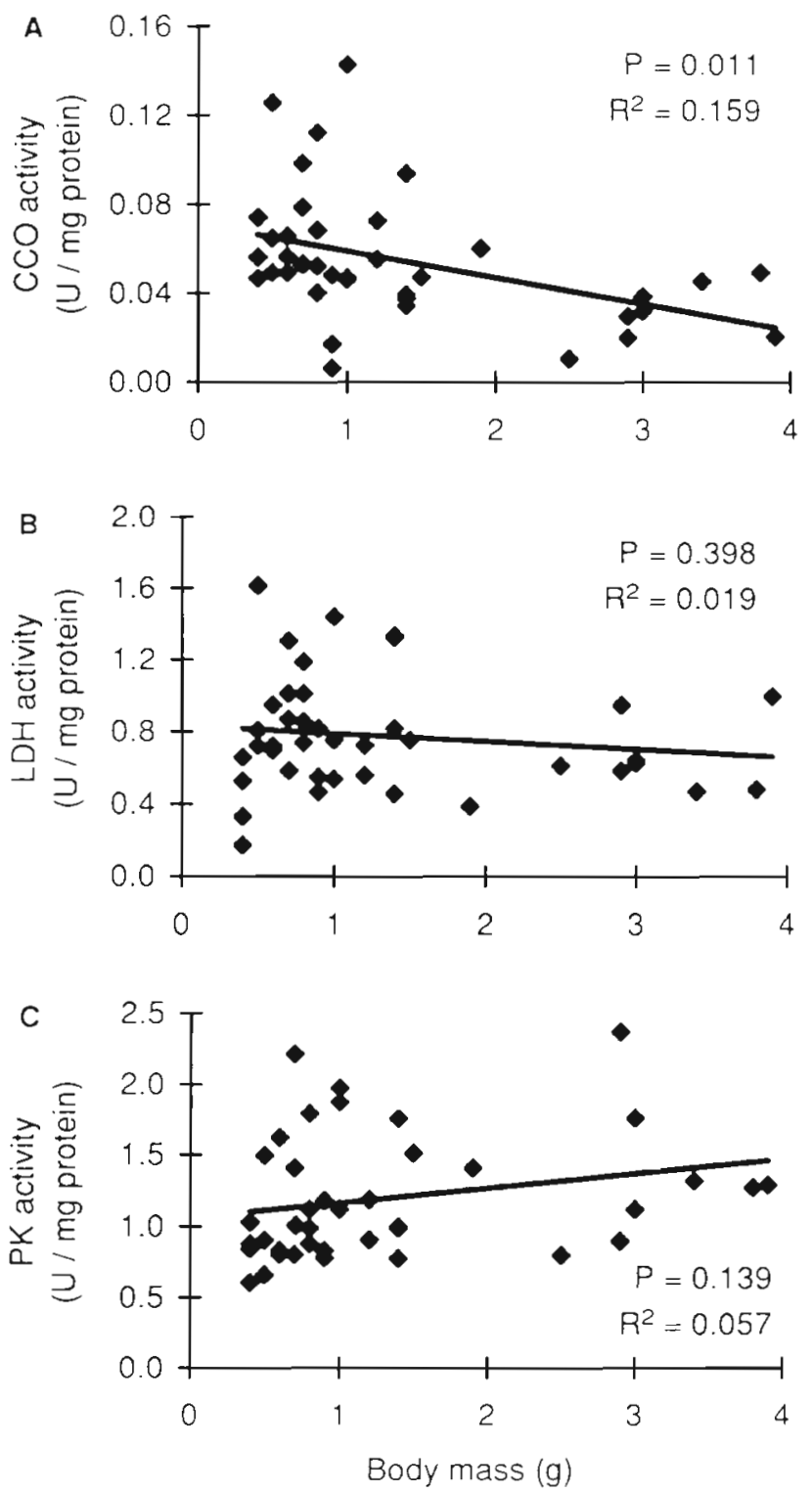

Fig. 1. Nereis virens. Effect of body mass on enzyme activities Units (U) are expressed in $\mathrm{mmol} \mathrm{min}^{-1}$

importance of aerobic metabolism for activity in $N$. virens. The lack of correlation between outcome of confrontation and $\mathrm{LDH}$ or PK activities indicates that outcome does not depend on maximal anaerobic capacities. As the oxygen debt of $N$. virens has been shown to be associated with increases in lactate concentration (Scott 1976, Scott et al. 1976), it is possible that this species relies mostly on anaerobic metabolism when oxygen tension decreases, as has been shown for other polychaete species (Cirriformia tentaculata and Arenicola marina) (Warren 1981, Schöttler et al. 1983). During prolonged periods of anaerobiosis, many polychaetes are able to generate different metabolic end products such as succinate, amino acids (alanine), and fatty acids (propionate and acetate) (for a review see Cammen 1987) Therefore alternative dehydrogenases could be implicated in the ATP generation during activity and partly explain the absence of a relation between PK or LDH activity and battle issue or duration. However as the the major end product of polychaetes in early anaerobiosis is lactate (Scott 1976 , Schöttler 1978, 1979) and since confrontations rarely last more than a few minutes, it is likely that the anaerobic metabolism mobilization during battle depends on LDH activation as the principal dehydrogenase.

If polychaetes use mostly aerobic metabolism for short aggressive interactions, one would expect a correlation between aerobic capacities and the outcome of competition. Again, no such correlation was found. Instead we found a significant correlation between aerobic capacities of winners and fight duration, such that those individuals with high aerobic capacities tended to win fights rapidly. Few studies have examined metabolic correlates of competitive interactions. Bennett \& Huey (1991) found that lizards that were dominant in paired encounters were also the faster of the size matched pair. By contrast, H. Guderley \& C. Garenc (unpubl.) found no significant differences in enzyme activities (PFK, LDH, CCO) between winners and losers of paired encounters in male threespine sticklebacks Gasterosteus aculeatus. These authors also found a significant relationship between fight duration and aerobic metabolism, but in their study it was the aerobic capacities of losers that were correlated with fight duration. The duration of confrontations could have important ecological consequences since short confrontations increase the chances of survival for both winners and losers by reducing the risk of predation.

Short fights may also provide important physiological benefits for these polychaete worms. A recent time budget activity study showed that individual Nereis virens spend a significant percentage of time irrigating their burrows (Miron et al. 1992b). Long fighting periods are typically followed by long irrigation periods (Miron et al. 1992a), suggesting that oxygen debts increase with competition intensity. These results indicate that confrontation induces anderobic mobilization. In some vertebrates, anaerobic mobilization occurs when most of the aerobic scope has been used (Beamish 1978). The excursions over the aerobic scope are very costly and their frequencies are inversely related to survival rates in fish (Priede 1977). Thus short confrontations may be advantageous for $N$. virens in that they might limit the mobilization of anaerobic metabolism and therefore increase survival. Similarly, $N$. virens individuals with high aerobic capacities might be at an advantage over those with lower aerobic capacities since they may limit their excursions into anaerobic metabolism. 
If high aerobic capacities are advantageous during fights, they may incur costs to individuals. For example, high aerobic capacities may be correlated with high basal metabolic rates, which could reduce the energy available for growth and reproduction. Thuesen \& Childress (1993) found that deep sea worms with high metabolic capacities (as determined by citrate synthase, PK, and LDH activities) also had higher oxygen consumption rates. Therefore it appears that metabolic potential and metabolic rates (probably standard and routine metabolic rates) are functionally linked and that a higher metabolic potential can lead to an increased energy expenditure.

We also estimated the effect of size and enzyme activity and found a significant albeit weak negative correlation between $\mathrm{CCO}$ activity and animal mass. However we found no significant mass differences between winners and losers, nor any correlation between mass and duration of the confrontation. Thus differences observed for CCO activity cannot be explained by mass differences among groups. The negative allometric trend in aerobic capacity is in agreement with the general trend observed in animals (Peters 1983, Schmidt-Nielsen 1984, Hochachka et al. 1988).

In the last decade, many studies have attempted to relate genetic variability to physiological performance (Pough 1989, Bennett 1991, Watt 1991, Scorci et al. 1995). The relationship between genetics and physiological traits could be partly determined by metabolic traits. For example, during cold acclimation in fish, the improvement of sustained swimming speed is related to increases in the quantity of mitochondria, as well as in the activity of enzymes of the aerobic pathway (citrate synthase and CCO) (Guderley \& Blier 1988). The acclimatory response to low temperature may be mediated by the differential regulation of genes coding for metabolic enzymes. Enzyme activities could prove to be good markers of metabolic potential in animals and hence could help us link physiological traits to genetic variability.

The present study on Nereis virens is one of the first to clearly indicate that aerobic capacity can have a significant impact on competitive interaction for habitat. Territoriality is crucial to $N$. virens survival since it serves essentially as a refuge against predators (Miron 1991). Intraspecific competition for burrow space occurs in the lower intertidal zone where adults are located. Agonistic interactions frequently occur between juvenile and mature individuals when, following their migration, juveniles attempt to settle into burrows already occupied by adults (Miron et al. 1992a). Aggressive encounters can also occur when mature individuals leave their burrows during the tidal cycle and re-enter occupied ones. Aggressive encounters typically result in the expulsion or the death of the intruder. Therefore, the ability to exploit a habitat will partly depend on the ability to defend a burrow with a minimum of injury. According to our study, this ability is related to the aerobic capacity of the animals. A recent study on sticklebacks has shown that the activities of CCO, LDH, and PK are heritable (Garenc 1996), which suggests that metabolic capacity can be under selective pressure. If high aerobic capacity is advantageous for competitive ability, why has selection not resulted in maximal aerobic capacity in all individuals? One possible answer is that there may be costs associated with high aerobic capacities such as body maintenance under periods of low food supply. Thus aerobic capacity is likely to be maintained at an optimal level through stabilizing selection. Future research on the variability and heritability of metabolic capacity as related to habitat exploitation in natural populations will greatly enhance our understanding of the physiological adaptations of organisms to their environments.

Acknowledgements. This work was supported by a grant from the Fond d'Investissement pour la Recherche of the Université du Québec à Rimouski to P.B. We are grateful to D. McNeil for his help with sampling and laboratory analyses and to $\mathrm{H}$. C Glemet for commenting on the manuscript. We also thank M. R. Joanet, director of the Parc National du Bic and the Ministère de l'environnement et de la Faune du Québec for allowing us to collect worms in the Parc National du Bic.

\section{LITERATURE CITED}

Beamısh FWH (1978) Swimming capacity. In: Hoar WS, Randall DJ (eds) Fish physiology, Vol 7. Academic Press, New York, p 101-187

Bennett AF (1987) Interindividual variability: an underutilized resource. In: Feder ME, Bennett AF, Burggren WW, Huey RB (eds) New directions in ecological physiology. Cambridge University Press, Cambridge, p $147-166$

Bennett AF (1991) The evolution of activity capacity. J Exp Biol 160:1-23

Bennett AF, Huey RB (1991) Studying the evolution of physiological performance. In: Futuyma D. Antonovics J (eds) Evolutionary biology, Vol 7 Oxford University Press, Oxford, p 251-284

Bradford MM (1976) A rapid and sensitive method for quantitation of microgram quantities of protein utilizing the principle of protein-dye binding. Anal Biochem 72:248-254

Cammen LM (1987) Polychaeta. In: Padiant J, Vernberg FJ (eds) Animal energetics, Vol 1 Academic Press, San Diego, p 217-259

Caron A, Olivier M, Desrosiers G, Hudier E, Côté S, Koutikonsky V, Miron G, Retière C (1993) Distribution spatiale d'une espèce benthique épitoque en zone intertidale: rôle de l'hydrodynamisme? Vie Milieu 43:85-93

Desrosiers G, Brêthes JC (1984) Etude bionomique de la communauté à Macoma balthica de la batture de Rimouski. Sci Tech Eau 17:25-30

Desrosiers G, Brêthes JC, Long BF (1984) L'effet d'un glissement de terrain sur une communauté benthique médio- 
Littorale du nord du golfe clu Saint-Laurent. Oceanol Acta $7(2): 251-258$

Desrosiers G, Caron A, Olivier M, Miron G (1994) Cycle de développement d'une population intertidale de Nereis virens (Polychaeta Nereidae) de l'estuaire maritime du Saint-Laurent. Oceanol Acta 17:683-695

Frings CS, Fendley TW, Dunn RT, Queen CA (1972) Improved determination of total serum lipids by Sulfo-PhosphoVanillin reaction. Clin Chem 18(7):673-674

Garenc C (1996) Capacité de nage maximal chez l'épinoche à trois épines (Gasterosteus aculeatus): ontogénèse, déterminants métaboliques et estimation de l'héritabilité. MSc thesis, Université Laval, Québec

Guderley H, Blier PU (1988) Thermal acclimation in fish: conservative and labile properties of swimming muscle. Can J Zool 66:1105-1115

Hochachka PW, Emmett B, Suarez RK (1988) Limits and constraints in the scaling oxidative and glycolytic enzymes in homeotherms. Can J Zool 66:1128-1138

Hochachka PW, Somero GN (1984) Biochemical adaptation Princeton University Press, Princeton, NJ

Hodges TK, Leonard RT (1974) Purification of plasma membrane bound adenosine triphosphatase from plant roots Methods Enzymol 22:392-406

Holloszy JO, Coyle EF (1984) Adaptations of skeletal muscle to endurance exercise and their metabolic consequences. J Appl Physiol 56:831-838

Miron G (1991) Définition et description du domaine vital et biologie comportementale chez le polychète Nereis virens (SARS). PhD thesis, Université du Québec à Rimouski Québec

Miron G, Desrosiers G (1990) Distributions and population structures of two intertidal estuarine polychaetes in the lower St. Lawrence estuary, with special references to environmental factors. Mar Biol 105:297-306

Miron G, Desrosiers G, Retière C (1992a) Organization of fighting in the polychaete Nereis virens (Sars) and the effects of residency on orientation. Behaviour 121:20-34

Miron G, Desrosiers G, Retière C, Masson S (1992b) Variations in time budget of the polychaete Nereis virens as a function of density and acclimation after introduction to a new burrow. Mar Biol 114:41-48

Newsholme EA, Leech AR (1983) Biochemistry for the med-

This article was submitted to the editor ical sciences. John Wiley \& Sons Lid, Chichester

Peters RH (1983) The ecological implication of body size. Cambridge University Press, New York

Pough FH (1989) Organismal performance and Darwinian fitness: approaches and interpretations. Physiol Zool 62 $199-236$

Priede IG (1977) Natural selection for energetic efficiency and relationship between activity level and mortality. Nature 267:610-611

Schmidt-Nielsen K (1984) Scaling: why animal size is so important. Cambridge University Press, Cambridge

Schöttler U (1978) Investigation of the anaerobic metabolism of the polychaete worm Nereis diversicolor $\mathrm{M}$. J Comp Physiol 125:185-189

Schottler U (1979) On the anaerobic metabolism of three species of Nereis (Annelida). Mar Ecol Prog Ser 1:249-254

Schottler U, Wienhausen G, Zebe E (1983) The mode of energy production in the lugworm Arenicola marina at different oxygen concentrations. I Comp Physiol 149: $547-555$

Scorci G, Swallow JG, Garland I Jr, Colbert J (1995) Quantitative genetics of locomotor speed and endurance in the lizard Lacerta vivipara. Physiol Zool 68(4):698-720

Scott DM (1976) Circadian rhythm of anaerobiosis in a polychaete annelid. Nature 262:811-813

Scott DM, Mazurkiewicz M, Leeman P (1976) The long term monitoring of ventilation rhythms of the polychaetous annelid Nereis virens Sars. Comp Biochem Physiol 53A 65-68

Thibault M, Blier PU, Guderley H (1997) Seasonal variation of metabolic organization in rainbow trout muscle Oncorhyncus mykiss. Fish Physiol Biochem 16(2):139-155

Thuesen EV, Childress JJ (1993) Metabolic rates, enzymes activities and chemical compositions of some deep-sea pelagic worms, particulary Nectonemertes mirabilis (Nemertea; Hoplonemertinea) and Poebius meseres (Annelida; Polychaeta). Deep Sea Res 40:937-951

Warren LM (1981) Respiratory adaptations to temporary hypoxia by the polychaete Cirriformia tentaculata. Comp Biochem Physiol A 69:321-324

Watt WB (1991) Biochemistry, physiological ecology, and population genetics - the mechanistic tools of evolutionary biology. Funct Ecol 5:145-154

Manuscript received: September 20, 1996

Revised version accepted: July 16, 1997 